\title{
Analisis Identifikasi dan Guilt pada Teori Dramatisme Kenneth Burke dalam Film "They Live 1988"
}

\author{
Achmad Sigit Syarifuddin ${ }^{1 *}$, Irwansyah ${ }^{2}$ \\ 1,2Pascasarjana Ilmu Komunikasi Universitas Indonesia \\ Jl. Margonda Raya, Pondok Cina, Kecamatan Beji, Kota Depok, Jawa Barat. \\ E-mail: ${ }^{1}$ Achmad.sigit01@ui.ac.id, ${ }^{2}$ irwansyah09@ui.ac.id
}

Received: June 2021; Accepted: October 2021; Published: December 2021

\begin{abstract}
According to Burke, Dramatism means humans can learn and understand motives in all human interactions through symbols. Burke sees that the motives behind people's actions are essential for analyzing and finding out why people do and say what they do. Apart from the dramatic Pentad which is one of the important concepts in dramatism, there are identification, guilt and ratio. There are six ways of identification, formal patterns, framing, ambiguous symbols, mystification, and scapegoats. There are two forms of guilt, namely mortification and victimage. There are two forms of guilt, mortification and labeling the enemy or the victim of victimage. This study aims to analyze existing data to present the basic findings of dramatism theory, identification and guilt in the film "They Life 1988". This research also retraces or provides a re-understanding of the fundamentals of Kenneth Burke's dramatism theory. The previous research data or secondary data use in this research used Kenneth Burke's dramatism theory, but did not mention the initial process of a dramatism theory. This research was conducted with a qualitative descriptive approach, by analyzing findings from previous research or secondary data which will generate basic findings as the results of the analysis, namely: identifying which there are six parts, namely identification, formal patterns, framing, ambiguous symbols, mystification and scapegoat. Then it generates guilt in which there are two parts, mortification and labeling of the enemy or the victim of victimage. The novelty in this research is using a qualitative descriptive approach to the object of research, which in this study is a movie using Kenneth Burke's dramatism theory. Movie continuously to develop rapidly thus the suggestion for further research is to use Kenneth Burke's dramatism theory as an analytical instrument and understand the initial process of the theory, namely identification and guilt.
\end{abstract}

Keywords: dramatism analysis; identify; guilt

\begin{abstract}
Abstrak
Dramatisme menurut Burke, manusia dapat mempelajari dan memahami motif dalam semua interaksi manusia melalui simbol-simbol. Burke melihat bahwa motif di balik tindakan orang, sangat penting untuk dianalisis dan mencari tahu mengapa orang tersebut melakukan dan mengatakan apa yang mereka lakukan. Selain Pentad dramatistik yang menjadi salah satu konsep penting dalam dramatisme, terdapat dua hal yang mendasar dari teori tersebut yakni mengidentifikasi dan rasa bersalah guilt. Dalam identifikasi terdapat enam elemen cara yakni: identifikasi, pola formal, pembingkaian, simbol yang ambigu, mistifikasi dan kambing hitam. Dalam rasa bersalah terdapat dua bentuk yang akan dilakukan, yakni mortifikasi dan pelabelan musuh atau yang menjadi korban victimage. Penelitian ini bertujuan untuk menganalisis data yang ada untuk menghadirkan temuan mendasar dari teori dramatisme yakni identifikasi dan rasa bersalah dalam film "They Live 1988". Penelitian ini juga menelusuri ulang atau memberikan pemahaman ulang tentang hal yang fundamental pada teori dramatisme Kenneth Burke. Pada data penelitian sebelumnya atau data sekunder yang digunakan dalam penelitian ini juga menggunakan teori dramatisme Kenneth Burke, namun dalam penelitian tersebut tidak memunculkan proses awal sebuah teori dramatisme. Penelitian ini dilakukan dengan pendekatan deskriptif kualitatif, dengan menganalisis temuan dari penelitian yang pernah dilakukan atau data sekunder yang nantinya akan menghadirkan temuan dari hasil analisis hal yang mendasar yakni: mengidentifikasi yang terdapat enam bagian yakni identifikasi, pola formal, pembingkaian, simbol yang ambigu, mistifikasi, kambing hitam. Kemudian menghadirkan rasa bersalah guilt yang didalamnya terdapat dua bagian yakni mortifikasi dan pelabelan musuh atau yang menjadi musuh atau korban victimage. Kebaruan dalam penelitian ini yakni menggunakan metode pendekatan deskriptif kualitatif pada objek penelitian yang berupa film dengan menggunakan teori dramatisme Kenneth Burke. Melihat perkembangan film yang begitu pesat, maka saran untuk penelitian selanjutnya yakni dapat menggunakan teori dramatisme Kenneth Burke sebagai instrumen Analisa dalam sebuah penelitian dan juga mengetahui proses awal sebuah teori tersebut yakni identifikasi dan rasa bersalah guilt.
\end{abstract}

Kata Kunci: analisis dramatisme, mengidentifikasi, rasa bersalah guilt 


\section{PENDAHULUAN}

Dalam kehidupan manusia komunikasi menjadi bagian penting yang tidak dapat terhindarkan. Manusia sebagai makhluk sosial adalah manusia yang berinteraksi berkomunikasi dan selalu hidup bersama dengan manusia lainnya (Sihombing, 2018). Secara sadar maupun tidak, manusia akan selalu melakukan proses komunikasi. komunikasi merupakan proses penyaluran informasi, ide, perasaan, penjelasan, pertanyaan dari orang ke orang lain maupun dari kelompok ke kelompok (Ulwani, Mailin dan Zainun, 2021). Akar katanya communis adalah communico, yang artinya berbagi (Hadi, Kurniawan dan Irwansyah, 2021). Menurut (Littlejohn et al., 2017) komunikasi merupakan sebuah proses yang berkaitan erat dengan keseharian kehidupan manusia, serta dapat mempengaruhi kehidupan manusia dengan menyampaikan informasi tentang kompleksitas, kekuatan dan keterbatasannya. Namun diketahui komunikasi tidak hanya sebatas disitu. Selain melakukan penyampaian pesan dan informasi, komunikasi memainkan peran penting dalam praktik-praktik persuasi, komunikasi juga memainkan peran penting dalam memahami maksud dari komunikasi tersebut.

Dikatakan dalam (Griffin et al., 2019) ketika kita melihat sebuah tontonan film, kita seolah-olah menjadi sebuah kritikus film yang mengomentari segalanya dalam film tersebut, namun yang dimaksud Burke adalah kondisi ketika manusia mencoba untuk membedakan motivasi di balik pesan yang terkadang jelas bahkan tersembunyi. Dari sini manusia melakukan aktivitas untuk memahami hubungan antara simbol yang digunakan penutur dan motif mereka dalam sebuah komunikasi.

Teori dramatisme Burke dapat dianggap sebagai suatu pendekatan untuk mempelajari dan mengkaji cara-cara mempengaruhi dan cara untuk menemukan unsur-unsur hubungan antar simbol yang digunakan orang untuk mempengaruhi orang lain (Griffin et al., 2019). Konsep mendasar dalam dramatisme adalah pemeriksaan atas perbuatan manusia dan perbuatan tersebut dapat terjadi sebagai perbuatan simbolis atau kongkrit, yang kemudian dianalisis lebih lanjut. Bagi Burke, hidup bukanlah layaknya seperti drama, melainkan hidup manusia itu sendiri adalah drama.

Dengan penganalisaan ini, hubungan dan kehidupan dapat dianalisis dengan cara yang sama seperti layaknya aktor atau pemeran yang diperankan dalam film. Dalam pandangan yang fundamental atau mendasar dari teori dramatisme adalah manusia terus menerus menggunakan simbol, karena mereka berkomunikasi melalui berbicara. Melalui simbol-simbol ini seseorang dapat mempelajari dan memahami motif dalam semua interaksi manusia. Burke melihat bahwa konsep motif di balik tindakan orang sangat penting untuk menganalisis dan mencari tahu mengapa orang melakukan dan mengatakan apa yang mereka lakukan dan katakan (Burke, 1969)

Dalam studi ini, penulis menjadikan penelitian sebelumnya menjadi landasan dalam penulisan jurnal penelitian. Peneliti melakukan pembacaan terhadap penelitian terdahulu yang membahas teori dramatisme Burke. Peneliti menelusuri bagaimana dramatisme digunakan pada penelitian terdahulu, bagaimana fenomena-fenomena yang mendasarinya, dan tentunya bagaimana teori dramatisme bekerja dalam sebuah penelitian. Penulis menemukan lima penelitian terdahulu, yang berjudul yang berjudul "It's All Your Fault: Kenneth Burke, Symbolic Action, and the Assigning of Guilt and Blame to Women" yang ditulis oleh (French dan Brown, 2011). Dalam penelitian tersebut berpendapat bahwa masalah obesitas dan pelecehan seksual keduanya mewujudkan pilihan bahasa yang menindas dan mengontrol persepsi perempuan tentang hak dan kemampuan mereka untuk membebaskan diri dari rasa motivication dan guilt. Melalui analisis peneliti mengungkapkan bagaimana konsep agency yang mendasari. 
Kemudian penelitan kedua terdahulu yakni "Pentad Analisis Pada Film Legend of The Guardian" yang ditulis oleh (Novitasari et al., 2015). Dalam penelitian terdahulu tersebut meneliti nilai-nilai makna kepahlawanan yang tersirat dalam sebuah film dengan menggunakan analisis dramatisme. Teori dramatisme menjadi sebuah landasan dengan metode penelitian pentad analisis. Hasil penelitian memperlihatkan bahwa representasi nilai-nilai kepahlawanan dalam film Legend Of The Guardians diperlihatkan dalam lima elemen unsur pentad yang terdiri atas, act yang selalu memperlihatkan adegan peperangan untuk menyelamatkan kerajaannya. Scene diperlihatkan dengan pemanfaatan cahaya yang rendah untuk memberikan unsur dramatis, dan menegangkan serta mencekam pada adegan peperangan dalam film . Agent diperlihatkan dengan karakter gagah dan berani, tidak mengenal menyerah, serta melindungi yang lemah, dan juga membela kebenaran. Agency ditunjukkan dengan adanya kegiatan peperangan. selanjutnya dan menjadi yang terakhir yakni purpose ditampilkan dengan tokoh yang memberantas kejahatan demi menyelamatkan makhluk yang mengalami kondisi ketertindasan serta mengembalikan kondisi kedamaian kerajaan burung hantu.

Kemudian yang ketiga ditemukan penelitian terdahulu "Make America Great Again" yang ditulis oleh (Lathi et al., 2018). Dalam penelitian dijelaskan bahwa dalam kampanye Trump, Trump dianggap menyerukan anggapan kehancuran Amerika yang kemudian menghasilkan sosok Trump menjadi satu-satunya penolong pada kehancuran tersebut. Dalam penelitian terdahulu ini dijelaskan pembabakan elemen-elemen pentad pada bagian-bagian pidato mengenai bagaimana semua pentad bekerja dalam analisis pidato kampanye pemilihan calon presiden. Asumsi-asumsi dasar pada penelitian terdahulu ini juga dijelaskan secara menyeluruh dan jelas dalam penuangannya. Penarikan rasio pada elemen pentad juga dijelaskan dengan adanya temuan kekhususnya pada elemen act dan agency. Penelitian mengenai pidato Trump dilakukan karena pada kasus fenomena pemilihan di Amerika, Trump adalah kasuistik yang fenomenal dan kontroversi mengenai pidato setelah George W. Bush.

Penelitian terdahulu keempat selanjutnya yang ditemukan yakni "Analisis Dramatistik Pentad Unsur Konsumerisme Dalam Film They Life 1988" yang ditulis oleh (Satjakoesoemah et al., 2020). Dalam penelitian terdahulu ini, penelitian dilakukan menggunakan objek pada film yang didalamnya dinilai adanya pesan-pesan konsumerisme. Penelitian ini kemudian menambahkan indikator konsumerisme untuk mengerucutkan hasil analisis pentad. penelusuran tinjauan literatur konsumerisme yang ada dalam penelitian tersebut sangat tersusun secara detail. Sesuai dengan judulnya, dalam penelitian ini menggunakan metode kualitatif dengan teknik analisis pentad dramatistik Burke. Pada penelitian ini, dapat disimpulkan bahwa film "They Live 1988" memuat adegan yang merepresentasikan bagaimana konsumerisme dapat mempengaruhi kehidupan masyarakat dan ditemukan adanya keterkaitan tentang apa yang disampaikan di dalam film They Live pada tahun 1988 tersebut dengan kondisi realitas masa kini.

Kemudian pada penelitian terdahulu kelima selanjutnya adalah penelitian mengenai komunikasi politik yang berjudul "Jokowi's Communication Dramatism On Mass Media During The 2019 Presidential Election" yang ditulis oleh (Putra, 2020). Dalam penelitian ini peneliti menggunakan kesuluruhan pentad dramatistik sebagai analisis debat politik Jokowi dalam pilpres 2019 secara detail dan spesifik. Selain menghasilkan temuan analisis dari elemen pentad, dalam penelitian ini juga mendapatkan banyak temuan-temuan baru yakni aktivitas politik yang dilakukan Jokowi maupun prabowo yang masing-masing aktivitas tersebut membawa ke konteks politik yang lebih kompleks. Pada kondisi tersebut Jokowi sangat diuntungkan dalam menguasai medan debat, karena Jokowi sudah mempunyai investasi aktivitas politik pernah menjadi presiden sebelumnya dibanding prabowo waktu itu. 
Pada penelitian ini, penulis akan berfokus pada salah satu literature review dari penelitian terdahulu atau sebelumnya yakni “Analisis Dramatistik Pentad Unsur Konsumerisme Dalam Film They Life 1988". Dalam penelitian tersebut tidak dijelaskan asumsi-asumsi yang mendasar dan bagaimana Pengidentifikasian awal serta rasa bersalah guilt bermula yang merupakan dasar yang penting dari teori Dramatisme. Hal ini penting untuk dilakukan karena selain menjadi sebuah tinjauan literatur, teori dramatisme harus menjadi alat analisis yang perlu dilihat secara fundamental, bersih dan dipahami secara menyeluruh sebagai instrumen analisisi. Maka, dalam penelitian ini, penulis akan menambahkan identifikasi yang mendasar dan rasa bersalah guilt yang menjadi dasar atau landasan penting dari sebuah teori dramatisme yang digagas oleh Kenneth Burke.

\section{TINJAUAN LITERATUR}

Dapat dikatakan bahwa keseluruhan titik awal teori dramatisme yakni pandangan manusia sebagai makhluk yang menggunakan, membuat dan menyalahgunakan simbol (Bobbit, 2004). Seluruh realitas manusia dibangun oleh struktur simbolik karena kita dianggap sebagai makhluk yang menggunakan simbol. Karena kita manusia, itu berarti kita menciptakan realitas kita melalui konstruksi bahasa (Burke, 1962). Penggunaan bahasa itu sendiri merupakan bentuk tindakan simbolik dan kualitas paling esensial dari interaksi manusia adalah implementasi pengalaman, tindakan dan niat ke dalam ekspresi linguistik (Burke, 1962). Menurut Burke, sistem simbolik merupakan pembeda yang memisahkan manusia dari hewan karena dunia hanya terdiri dari gerakan dan bentuk elemen materialistis. Manusia sebagai makhluk yang menggunakan simbol-simbol, adalah inti dari teori dramatisme. Simbol merupakan pelaksana tindakan manusia, tepatnya kemampuan manusia untuk mengeksploitasi dan menggunakan struktur simbolik yang menjadikan atau mengklasifikasikan bahwa kita merupakan manusia.

Dapat dikatakan juga bahwa karena tujuan utama dramatisme Burke adalah untuk menjelaskan motif manusia yang ada di balik interaksi simbolik. Seperti yang dikatakan (Downling, 2008) dramatisme Burke ini merupakan metode untuk menganalisis hubungan dan motif manusia, kita dapat memahami bagaimana manusia berhubungan dan mengapa mereka bertindak seperti demikian. Perlu digaris bawahi bahwa teori dramatisme tidak menawarkan kebenaran objektif untuk masalah tertentu, meskipun tujuan utamanya adalah untuk mengungkapkan motif terselubung dari pembicara. Maka dari itu, dramatisme tidak dapat dijadikan sebagai satu-satunya cara untuk melakukan analisis retoris tekstual, melainkan salah satu dari banyak cara. Menurut (Lathi et al., 2018) kekuatan besar dan kelemahan terbesar dari teori dramatisme terletak pada konsepnya yang sebagian ambigu dan agak tidak berwujud, pada saat yang sama, ia menawarkan alat yang serius dan fungsional untuk analisis retoris yang menyeluruh, tetapi ia hadir dengan tanggung jawab untuk memahami bahwa analisis yang dilakukan akan kurang bermanfaat jika penyajian metode dan hasil yang digunakan tidak memadai.

\section{Mengidentifikasi}

Identifikasi merupakan proses substansi dan kepentingan berbagai orang dipertemukan. Hal tersebut juga bisa menjadi proses di mana orang percaya bahwa substansi dan kepentingan bertemu atau kemudian manusia dibuat untuk percaya atas hal yang terjadi (Burke, 1962 ). Dalam konteks identifikasi ini, kata substansi digunakan untuk menggambarkan prinsip, perasaan, ide, pengalaman, persepsi, sikap, nilai dan gambaran individu (Burke, 1962). Dalam pandangan dramatis (Burke, 1962) substansi menggambarkan bagaimana seseorang telah 
dikonstruksi secara simbolis. kondisi ini muncul dengan sendirinya ketika seseorang menggunakan kosa kata tertentu dengan cara mereka menggambarkan orang, benda, dan masalah (Larson, 2010). Keseluruhan konsep identifikasi harus dianggap sebagai proses bertahap daripada absolut. Melalui identifikasi, pembicara berkembang untuk meyakinkan pendengarnya dan untuk menciptakan komunitas tertentu dan perasaan persatuan komunal, dimana mereka pendengar adalah bagian dari. Ketika pembicara dan khalayak dibuat atau dikondisikan menjadi tampak sama. Maka dari itu, minat, nilai dan sikap pembicara dan khalayak pun mulai menjadi memiliki kesamaan (Burke, 1962).

Cara pertama untuk membuat identifikasi (identifying) di antara hadirin adalah dengan mengidentifikasi tata krama dengan mereka. Seorang pembicara dapat melakukan ini dengan menggunakan bahasa yang sama, gerak tubuh yang sama, gambar, sikap, gagasan dan hierarki. Burke menyatakan bahwa mengidentifikasi adalah bentuk termudah untuk membuat identifikasi antara pembicara dan audiensnya.

Cara kedua disebut pola formal (formal patterns). Penggunaan pola formal memancing audiens dan berpartisipasi dalam bentuk percakapan yang dilakukan dan kemudian mengambil bagian dalam apa yang sedang dikatakan. Efek pemersatu dari timbal balik ini menjelaskan mengapa penggunaan pola formal cukup berfungsi dalam menciptakan identifikasi (Burke, 1962).

Cara ketiga adalah pembingkaian (framing), yang dimaksud Burke (1962) berarti penggunaan ide, gambar dan persepsi yang dapat dilakukan pembicara mendefinisikan atau mengasosiasikan seseorang atau alasan untuk masalah lain apa pun, objek atau orang yang diinginkan pembicara.

Cara keempat untuk membuat identifikasi adalah melalui penggunaan simbol yang ambigu (ambiguous symbols). Kemampuan manusia untuk membuat, menggunakan, dan menyalahgunakan simbol sebagian besar didasarkan pada kenyataan bahwa ambiguitas simbol dapat dimanipulasi untuk menciptakan pemahaman tentang masalah tertentu. Penggunaan simbol yang ambigu bisa jadi misalnya mengacu pada "pemahaman umum" tanpa benar-benar mendefinisikannya secara spesifik beserta dengan maksud dan konteksnya (Burke, 1962).

Cara kelima disebut mistifikasi (mystification). Burke menjelaskan bahwa mistifikasi terjadi ketika motif universal dan umum seperti kehendak tuhan atau takdir, digunakan untuk menyembunyikan motif situasional yang sebenarnya (Burke, 1962).

Cara keenam dan terakhir yang paling umum digunakan untuk membuat identifikasi oleh Burke disebut kambing hitam (scapegoating). Mengkambinghitamkan memiliki artian menyalahkan orang lain atau sekelompok orang tertentu yang mengakibatkan menciptakan persatuan dalam komunitas sosial lain. Hal ini disebabkan oleh kenyataan bahwa segala tantangan dan tragedi atau peristiwa yang terjadi di masyarakat dapat disalahkan atau disebut dengan kambing hitam. Dengan cara ini komunitas melakukan pembelaan dirinya sendiri dan dapat tampil kembali dengan wajah citra baru (Burke, 1962).

Karena keragaman konsep identifikasi, tidak sulit untuk memahami mengapa hal ini dianggap sebagai konsep kunci dalam teori dramatisme Burke. Dalam penelitian ini, menurut Griffin (2019), tanpa adanya identifikasi tidak ada persuasi. Identifikasi pikiran ini dapat dianggap sebagai konsep fundamental terhadap semua pidato yang bertujuan untuk mempengaruhi pendapat orang. Apakah pidato ini politis atau tidak, atau memiliki maksud lain dibalik pesannya atau tidak. 


\section{Rasa Bersalah (Guilt)}

Dalam dramatisme Burke, konsep rasa bersalah adalah hal yang fundamental Burke untuk melihat bahwa manusia merupakan makhluk yang menggunakan simbol. Fakta bahwa kita manusia menciptakan, menafsirkan, dan menggunakan simbol, secara bersamaan mengarah pada penciptaan hierarki, pemikiran negatif, dan elemen kesempurnaan. Unsur-unsur negatif dan kesempurna kemudian mengarah pada konsep rasa bersalah. Seperti Downling (2008) mengatakan bahwa rasa bersalah memotivasi orang untuk mencari penebusan dan membutuhkan korban. Burke melihat bahwa bahasa yang digunakan oleh manusia, secara alami dapat berkembang menjadi suatu bentuk tatanan sosial yaitu hierarki (Bobbit, 2004).

Dalam memandang dunia, Burke menganggap dunia merupakan hirarkis dalam struktur sosial dan dengan demikian teori dramatisme mengamati dunia dari sudut pandang yang sama. Keberadaan murni hierarki dalam masyarakat kita dan dalam interaksi manusia menciptakan penerimaan dan penolakan. Burke melihat elemen penolakan, dan dia menyatakan bahwa rasa bersalah itu sendiri melekat karena manusia tidak dapat menyetujui dan menerima semua bentuk hierarki tradisional dalam masyarakat kita. Sebagai konsekuensi dari hierarki ini, orang terusmenerus bertujuan untuk mengontrol status sosial mereka dan seseorang menggunakan proses siklus kesalahan dan penebusan agar mereka dapat membawa perubahan dan pertumbuhan ke situasi hierarki mereka.

Dalam melakukan pembebasan dari rasa bersalah guilt, burke menganggap hanya ada dua acara, yakni melalui Mortifikasi (mortification) dan Korban atau pelabelan musuh (victimage). Mortifikasi dapat diartikan sebagai tindakan. Tindakan di mana pihak atau orang yang bersalah mengorbankan diri mereka sendiri dengan mengakui kesalahan mereka atau dengan memohon pengampunan atau meminta maaf. Dengan cara ini, orang tersebut dapat menenangkan struktur sosial dan keseimbangan masyarakat di mana perbuatan salah dilakukan. Korban atau pelabelan musuh merupakan dari pengalihan korban atau label kambing hitam atau mencari orang lain untuk disalahkan atas kesalahan yang dibuat. Untuk dapat berhasil dalam melaksanakan metode penghapusan rasa bersalah ini, pengorbanan yang dilakukan melalui mortifikasi atau kambing hitam yang disalahkan, harus memiliki kondisi dan kadar yang proporsional dengan kesalahan yang telah dilakukan. Jika metode penghapusan rasa bersalah tidak seimbang atau proses pengorbanan atau pihak yang dinyatakan bersalah tidak cukup untuk menyesuaikan dengan kejahatan, maka usaha tersebut tidak akan berhasil dan siklusnya tidak akan selesai atau permasalahan akan tetap akan terjadi (Brock et al., 1990).

Rasa bersalah dianggap sebagai bagian fundamental dari bahasa, dan dengan demikian menjadi penting untuk dikategorikan menjadi makhluk, yakni manusia. Karena unsur rasa bersalah merupakan bagian penting dalam definisi siklus rasa bersalah, orang dapat menyatakan bahwa percakapan yang mengarah pada perasaan bersalah adalah bagian penting dari realitas retoris dan dunia kita. Dengan kata lain percakapan yang membuat orang merasa bersalah akan selalu diminati (Winslow, 2007). Menurut Burke (1962) ini adalah manifestasi dari karakteristik yang tidak sempurna dari kepribadian manusia. Jauh di lubuk hati seseorang mencari pemurnian dari rasa bersalah karena alasan mendasar bahwa rasa bersalah dianggap sebagai perasaan dan keadaan yang tidak menyenangkan. Ini menuntun seseorang untuk mencari pengampunan atau dalam hal ini pembicara kepada pendengarnya, untuk dapat diterima dan direstui kembali (Burke 1962). 


\section{Pentad Dramatistik}

Masuk ke dalam pentad daramatistik Burke, kritikus atau peneliti menelusuri maksud di bawah permukaan untuk mengidentifikasi motif secara kompleks seorang pembicara atau penulis. Seperti yang dikatakan Burke, ini adalah cara singkat bagi kritikus retoris untuk "membicarakan pembicaraan mereka" dengan cara yang bermakna (Griffin, 2019). Dengan penggunaan pentad dramatistik, seseorang dapat memahami dan menganalisa tindakan simbolik. Metode Burke menawarkan cara untuk mengungkap dan memahami motif manusia atau kemudian menjadi sarana untuk mewujudkan atribut motif melalui penggunaan bahasa. Menerapkan pentad Burke menjadi sebuah cara untuk mengatur pemikiran tentang masa depan (Sharer, 2004)

Dengan menggunakan pentad dramatistik sebagai instrumen untuk melakukan analisis, seseorang dapat memeriksa tindakan orang dengan menganalisis simbol-simbol yang digunakan dalam bahasa mereka dan motif potensial mana yang tersembunyi di balik penggunaan simbolsimbol tertentu (Hansen, 1996). Dengan kata lain, dengan pemanfaatan metode pentad dramatistik, seseorang dapat mengidentifikasi dan memberi nama motif yang tersembunyi di balik tindakan tersebut. Pentad dramatistik terdiri dari lima elemen dramatistik yang kemudian digunakan untuk menganalisis dan memeriksa teks yang dipilih. Elemen dari lima dramatistik adalah act, agent, agency, scene dan purpose. Menurut Burke (1969) untuk membuat interpretasi yang dapat dibenarkan tentang motif pembicara, seseorang atau peneliti harus dapat memahami "act" tindakan (apa yang terjadi dalam ide tindakan), mendefinisikan "agent" (siapa, orang atau seseorang dalam sifat seseorang yang melaksanakan tindakan), "agency" (cara apa yang digunakan agen untuk melakukan tindakan tersebut), dan "scene" (latar belakang situasi dan adega di mana tindakan itu terjadi), Selain itu, apa "purpose" tujuan dari tindakan tersebut (Burke, 1969).

Penjabaran lima elemen ini menjelaskan penggunaan pentad dramatistik. Urutan sebenarnya dari elemen-elemen tersebut tidak terlalu penting karena ide dasar dari metode ini adalah tentang keutuhan dan satuan wujud pentad yang bermaksud hadirnya semua lima elemen bersama-sama. Meskipun demikian tentu saja penting untuk menamai tindakan di hadapan agensi agar entitas yang sebenarnya masuk akal sebagai alat untuk analisis yang kredibel. Pertanyaan-pertanyaan yang diajukan setelah unsur-unsur yang dinamai tersebut bukanlah bagian dari latar belakang teori, melainkan suatu sarana visualisasi, agar pembaca dapat memahami dengan jelas tujuan unsur-unsur dalam pentad drama.

Unsur-unsur dari pentad dramatis:

1. Tindakan "act" - apa yang terjadi?

2. Agen "agent" - siapa yang melakukan tindakan tersebut?

3. Adegan "scene" - di mana dan kapan aksi itu berlangsung?

4. Agensi "agency"- bagaimana tindakan tersebut dilaksanakan?

5. Tujuan "purpose" - apa motif tindakan tersebut?

Dengan penggunaan model pentad dramatistik sebagai alat analisis, seseorang dapat mendefinisikan dan menamai berbagai tingkat pengaruh dari dasar identifikasi. Tujuan Burke adalah untuk membuat para peneliti menggunakan metode untuk mengerahkan diri mereka sendiri dengan setiap elemen secara cukup dan di sisi lain untuk mengenali hubungan korelatif di antara mereka. Unsur agen dipilih atas dasar tujuan - motif dibalik agen tersebut. Sebaliknya elemen tindakan membutuhkan adegan dan agen, yang semuanya membimbing agensi. Burke sendiri menggarisbawahi pentingnya memahami unsur-unsur pentad dramatistik secara keseluruhan. 
Bahkan seperti yang dijelaskan burke bahwa pentad dramatistik adalah alat yang kompleks untuk mengetahui motif seorang pembicara, seseorang tidak dapat hanya menekankan pada elemen terakhir dari pentad: yakni "purpose". Motif seorang pembicara melalui analisis hanya dapat diperoleh dengan penggunaan yang koheren dari semua elemen seperti yang sudah dijelaskan di atas. Perlu menggarisbawahi pentingnya pemahaman tentang hal ini ketika menggunakan metode, ketika meliput konsep manusia dan motivasinya, seseorang harus memasukkan semua elemen pentad dramatistik (Brock et at.,1990).

\section{Rasio}

Setelah kritikus memberi label pada act, agent, agency, scene dan purpose, selanjutnya adalah membedakan kepentingan relatif yang diberikan pembicara kepada masing-masing dari lima elemen ini . Kritikus dapat memulai dengan mengidentifikasi dua elemen pentad yang paling ditekankan dalam pidato (Griffin, 2019). Kedua elemen pentad menciptakan kesimpulan dominan atau "ratio" yang memberikan wawasan paling luas atau menonjol terkait motivasi pembicara (Burke, 1969).

Dalam beberapa kasus analisis, salah satu elemen dapat memunculkan salah satu lebih dominan, daripada unsur-unsur yang lain. Di sisi lain, terdapat juga banyak kesatuan antar elemen. Pentad dramatis sebagai alat dan metode analisis mampu mengungkapkan kemungkinan, pembagian, dan kesatuan. (Brock et al., 1990). Aspek persatuan, pembagian dan kemungkinan dominasi satu elemen berpotensi mengarah pada situasi di mana beberapa elemen agak tumpang tindih karena sifat khusus dari elemen-elemen tertentu ini. Misalnya, ketika mendeteksi elemen act dan agency, dapat dipahami untuk melihat bagaimana mereka mungkin tumpang tindih karena elemen act menjelaskan apa yang terjadi dan elemen agent menjelaskan bagaimana act itu terjadi. Ketika menganalisis kasus melalui ruang lingkup dramatisme, perlu diperhatikan bahwa prinsip dasarnya dibangun oleh gagasan bahwa kita harus dapat melihat perbedaan dalam berbagai hal dan membedakannya satu sama lain. Sebagai manusia yang menggunakan simbol, manusia tidak hanya mendeteksi perbedaan dalam berbagai hal, tetapi kami juga menciptakan, membandingkan, dan mengekspresikannya baik secara sadar atau tidak ataupun tidak (Rountree, 2010).

\section{METODE PENELITIAN}

Dalam penelitian ini digunakan metode deskriptif kualitatif dengan menggunakan analisis data dari penelitian terdahulu yang dilakukan pada objek yang diteliti. Penelitian ini menggunakan metode pendekatan deskriptif kualitatif. Penelitian deskriptif merupakan teknik pengumpulan data berdasarkan faktor yang menjadi pendukung terhadap objek penelitian, kemudian faktor-faktor tersebut dianalisis yang kemudian diungkap peranannya (Arikunto, 2010). Pada sebuah tahapan pengumpulan data penelitian, peneliti menggunakan sumber data sekunder. Menurut (Neuman, 2017) pengumpulan mengenai berbagai literatur sebelumnya dapat disatukan dalam empat langkah yaitu: (1) Mencari semua penelitian potensial pada suatu topik atau pernyataan penelitian tertentu; (2) Mengembangkan kriteria yang konsisten dan studi layar untuk relevansi dan menyaring penelitian untuk memperoleh relevansi dan kualitas; (3) Mengidentifikasi dan mencatat informasi menjadi temuan yang luas; (4) Menarik kesimpulan berdasarkan temuan tersebut.

Objek penelitian ini merupakan Film They Live 1988 berlandaskan penelitian terdahulu "Analisis Dramatistik Pentad Unsur Konsumerisme Dalam Film They Life 1988" yang ditulis oleh (Satjakoesoemah et al., 2020), dengan berupa data sekunder dari penelitian 
terdahulu yang berupa rujukan objek yakni berupa karya film. Penelitian deskriptif kualitatif digunakan untuk mengetahui bukti-bukti unsur yang mendasar dari teori dramatisme yakni: identifikasi dan rasa rasa bersalah guilt dalam film "They Live 1988". Langkah analisis yang dilakukan yakni dengan melakukan pembuktian tahapan mendasar dari teori dramatisme yakni: identifikasi dengan enam cara yakni, identifikasi, pola formal, pembingkaian, simbol yang ambigu, mistifikasi, kambing hitam. Kemudian melakukan analisis dan pembuktian pada hal yang mendasar pada teori dramatisme rasa bersalah atau guilt.

Pengambilan kesimpulan, data yang hadirkan kemudian dianalisis dan dikaitkan dengan teori sehingga dapat diambil kesimpulan bahwa film "They Live 1988" apakah mengandung substansi atau hal yang mendasar pada teori dramatisme dengan bukti identifikasi, pola formal, pembingkaian, simbol yang ambigu, mistifikasi, kambing hitam, dalam konteks identifikasi ini, kata substansi digunakan untuk menggambarkan substansi bagaimana seseorang telah dikonstruksi secara simbolis (Burke, 1962). kemudian rasa bersalah guilt, yang didalamnya terdapat mortifikasi dan pelabelan korban atau musuh victimage yang mana hal tersebut menuntun seseorang untuk mencari pengampunan atau dalam konteks hal ini pembicara kepada pendengarnya, untuk dapat diterima dan direstui kembali (Burke 1962). Mengetahui hal yang mendasar dari teori dramatisme Burke sangat penting dilakukan untuk bisa mendalaminya yang kemudian secara sahih pada teori dramatisme Burke pada tahapan yang lebih komples dilakukannya analisis pentad dramatistik seperti penelitian terdahulu yang dijadikan dasar permasalahan penelitian. Namun dalam penelitian ini, penulis tidak melakukan analisis pentad dramatisitik karena dalam penelitian ini mencoba menelusuri ulang serta menambahkan kekurangan dari hal yang mendasar dari teori dramatisme

\section{HASIL DAN PEMBAHASAN \\ Identifikasi}

Menurut Burke (1962) Identifikasi merupakan adalah proses substansi dan kepentingan berbagai orang dipertemukan. Hal tersebut mengisyaratkan bahwa proses di mana orang percaya bahwa substansi dan kepentingan bertemu atau kemudian manusia dibuat untuk percaya atas hal yang terjadi. Melalui identifikasi, pembicara berkembang untuk meyakinkan pendengarnya dan untuk menciptakan komunitas tertentu dan perasaan persatuan komunal, dimana mereka pendengar adalah bagian dari. Ketika pembicara dan khalayak dibuat atau dikondisikan tampak sama, maka minat, nilai dan sikap pembicara dan khalayak pun mulai menjadi memiliki kesamaan (Burke, 1962). Maka dari itu peneliti akan memaparkan temuan proses identifikasi dalam film "They Life 1988".

Cara pertama untuk membuat identifikasi (identifying) di antara hadirin adalah dengan mengidentifikasi tata krama sendiri dengan mereka. Jika dalam kasuistik ini, hadirin disematkan pada kondisi masyarakat yang ada dalam film They Live. Digambarkan pada kondisi tersebut seorang yang bernama John Nada (kelompok perubahan) karena John berbicara lancang terhadap bos kontraktor yang mana John seketika langsung mempersoalkan upahnya, disaat setelahnya orang bernama Frank muncul dan menimpali perkataan John yang tidak dijawab ketus oleh bosnya pada menit 07:10 "Bos: Tidak boleh tidur ditempat ini, tidurlah di tempat lain. John: Permisi, kapan aku dibayar atas pekerjaan ini?. Bos: Kamis. Frank: Apakah kau membutuhkan tempat tinggal ? Ada tempat di jalan 4th street. Mereka punya makanan hangat dan tempat mandi. Kalau kau mau akan kutunjukkan padamu". Frank menawarkan ajakan untuk bergabung di tempat tinggalnya yaitu penampungan tunawisma. Kondisi masyarakat yang digambarkan di 
penampungan tersebut adalah kemiskinan yang mana John dan Frank sama-sama tidak mempunyai tempat tinggal.

Cara kedua disebut pola formal (formal patterns). Penggunaan pola formal memancing audiens dan berpartisipasi dalam bentuk percakapan yang dilakukan dan kemudian mengambil bagian dalam apa yang sedang dikatakan. Yang menarik dari film ini yang pada awal menit ke 04:00 ditampakkan seorang yang sedang berpidato di tempat umum yang dia mengatakan "Mereka menggunakan lidahnya untuk menipumu, Bibir mereka berbisa, Mulut mereka penuh kepahitan dan kutukan, Takut akan tuhan, tidak takut didepan mata banyak orang, Mereka telah mengambil hati dan pikiran para pemimpin kita, Mereka telah membutakan kita terhadap kebenaran, Hati nurani kita telah rusak, Mengapa kita menuhankan ketamakan?, Karena diluar batas kemampuan kita, mereka memang kita, Bertengger diatas kita, dari lahir hingga mati, menguasai kita, Mengendalikan kita, mereka adalah majikan kita, Bangkitlah mereka semua disekitarmu". Yang membuat menarik adalah orang tersebut seorang tuna netra atau buta. Hal tersebut kemudian sangat memancing banyak orang orang disekitarnya yang kemudian terkesima dalam pidatonya. Ternyata orang tersebut adalah anggota kelompok perubahan. Efek pemersatu dari timbal balik ini menjelaskan mengapa penggunaan pola formal cukup berfungsi dalam menciptakan identifikasi (Burke, 1962).

Cara ketiga adalah framing (framing), yang dimaksud (Burke, 1962) berarti penggunaan ide, gambar dan persepsi yang memungkinkan pembicara mendefinisikan atau mengasosiasikan seseorang atau alasan untuk membingkai dengan masalah lain, objek atau orang yang diinginkan pembicara. Ditampilkan dalam sebuah TV yang didalamnya ada anggota kelompok perubahan yang berpidato. Pria yang berpidato tersebut digambarkan alih-alih sedang melakukan pembajakan saluran TV yang kemudian digunakan untuk melakukan kampanye politik. Dalam pidatonya pada menit ke 12:36 pria tersebut mengatakan "Kemiskinan semakin merebak, Hak asasi manusia tidak ada, Dalam sistem penindasan mereka, tanpa kita sadari, kita adalah kaki tangannya, Niat mereka untuk memerintah terletak pada penghancuran kesadaran, Kita telah terbuai tanpa sadar, Mereka telah membuat kita acuh tak acuh, Kita hanya fokus pada keuntungan kita sendiri". Dalam pembajakan saluran TV tersebut menghasilkan upaya pembingkaian permasalah atau pelemparan issue yang sedang terjadi yang disampaikan oleh anggota kelompok perubahan kepada penonton TV.

Cara keempat untuk membuat identifikasi adalah melalui penggunaan simbol yang ambigu (ambiguous symbols). Kemampuan manusia untuk membuat, menggunakan, dan menyalahgunakan simbol sebagian besar didasarkan pada kenyataan bahwa ambiguitas simbol dapat dimanipulasi untuk menciptakan pemahaman tentang masalah tertentu. Dalam film, John dan Frank mencoba membuat simbol ambigu dalam pemaknaan yang mengisyaratkan pengambilan sikap sebuah permasalah. Untuk ikut campur atau menjadi netral dalam hidup. Frank mengatakan pada menit 21:30 "Frank: Biarkan saja, ini bukan urusanku dan urusanmu! Aku da pekerjaan saat ini, Aku hanya terus berjalan di garis putih, Aku tak peduli siapapun, tidak ada yang menggangguku, dan kau harus melakukan hal yang sama!, John: Garis putih ditengah jalan. Itulah tempat terburuk untuk mengemudi”. Penggunaan simbol yang ambigu bisa jadi misalnya mengacu pada "pemahaman umum" tanpa benar-benar mendefinisikannya secara spesifik beserta dengan maksud dan konteksnya (Burke, 1962).

Cara kelima disebut mistifikasi (mystification). Burke menjelaskan bahwa mistifikasi terjadi ketika motif universal dan umum seperti kehendak tuhan atau takdir, digunakan untuk menyembunyikan motif situasional yang sebenarnya (Burke, 1962). Pada mistifikasi ini, ditunjukkan pada menit 04:00 yang mengatakan "takut akan tuhan, tidak takut didepan mata 
banyak orang". Pada awal film terdapat pidato panjang yang dilakukan oleh anggota kelompok perubahan yang memasukkan mistifikasi pada konteks pidatonya.

Cara keenam dan terakhir yang paling umum digunakan untuk membuat identifikasi oleh Burke disebut kambing hitam (scapegoating). Mengkambinghitamkan memiliki artian menyalahkan orang lain atau sekelompok orang tertentu yang mengakibatkan menciptakan persatuan dalam komunitas sosial lain. Dalam temuan ini scapegoating dihadirkan pada menit 10:37 yang mengatakan "Frank: Seluruh kesepakatan adalah jenis permainan gila, Nama permainan ini adalah: buatlah kehidupan, jalani kehidupan sebenarnya, Setiap orang mengedepankan dirinya sendiri, Kau bebas melakukan apa yang kau bisa, Tapi aku akan melakukan yang terbaik untuk menghancurkanmu, Lalu bagaimana caramu sukses?. John:Aku akan mencari uang dan menunggu waktunya, Aku percaya amerika, aku ikuti aturannya" yang didalamnya memuat seorang John yang harus mematuhi cara hidup Amerika dengan kondisinya yang serba kekurangan. Kondisi seperti ini, diilhami oleh masyarakat setempat bahwa adanya budaya yang buruk yang sedang dianut. Dengan cara ini, komunitas melakukan pembelaan dirinya sendiri dan dapat tampil kembali dengan wajah citra baru (Burke, 1962).

\section{Guilt}

Dalam dramatisme Burke, konsep rasa bersalah merupakan sebuah hal fundamental Burke untuk melihat bahwa manusia merupakan makhluk yang menggunakan simbol. Fakta bahwa kita adalah manusia yakni menciptakan, menafsirkan, dan menggunakan simbol, secara bersamaan mengarah pada penciptaan hierarki, pemikiran negatif, dan elemen kesempurnaan. Menurut (Burke, 1962) ini adalah manifestasi dari karakteristik yang tidak sempurna dari kepribadian manusia. Jauh di lubuk hati seseorang mencari pemurnian dari rasa bersalah karena alasan mendasar bahwa rasa bersalah dianggap sebagai perasaan dan keadaan yang tidak menyenangkan. Ini menuntun seseorang untuk mencari pengampunan atau dalam hal ini pembicara kepada pendengarnya, untuk dapat diterima dan direstui kembali (Burke, 1962).

Dalam melakukan pembebasan dari rasa bersalah, burke menganggap hanya ada dua acara, yakni melalui Mortifikasi (mortification) dan Korban atau pelabelan musuh (victimage). Mortifikasi dapat diartikan sebagai tindakan dimana-mana pihak atau orang yang bersalah mengorbankan diri mereka sendiri dengan mengakui kesalahan mereka atau dengan memohon pengampunan atau meminta maaf. Dengan cara ini orang tersebut menenangkan struktur sosial dan keseimbangan masyarakat di mana perbuatan salah telah terjadi. Korban atau pelabelan musuh victimage,di sisi lain adalah dari pembentukan kambing hitam atau mencari orang lain untuk disalahkan atas kesalahan dan kesalahan yang dibuat.

Kasuistik dalam penelitian ini memperlihatkan bagaimana guilt mulai dirasakan oleh John. Pada menit 32:25 hingga menit 38:35. Dalam kondisi lingkungannya menggambarkan adanya kondisi tersebut terjadi sebuah kondisi John yang sedang berada ditengah kota setelah mengenakan kacamata buatan kelompok perubahan. Kacamata tersebut diciptakan untuk melihat kondisi yang sebenarnya terjadi. Kondisi yang sebenarnya dalam objek ini yaitu sebuah kondisi di bumi yang dipenuhi oleh alien yang mengakibatkan banyak permasalahan yang terjadi. Dalam kondisi rasa bersalah yang dialami oleh John dan kelompok perubahan, tidak adanya temuan untuk dapat dihadirkannya mortifikasi atau meminta maaf bahwasannya kondisi yang sedang terjadi bukan berasal dari John dan kelompok perubahan. John dan kelompok perubahan merasakan rasa bersalah ketika mereka tidak dapat melakukan edukasi terkait pemahaman politik kepada masyarakat dan lingkungannya. Diperlihatkan dalam film, bahwa John merasa bersalah jika tidak dapat memberitahu Frank tentang kondisi bumi yang sebenarnya sedang dijajah oleh 
alien. Bahkan John memilih untuk bertikai dengan Frank, karena Frank tidak ingin mengenakan kacamata hitam yang disarankan John. Meskipun pada akhirnya Frank menuruti John untuk memakai kacamata hitam.

Ketika Frank sudah memakai kacamata hitam buatan kelompok perubahan, seketika rasa bersalah Frank dan John memuncak. Mereka memiliki rencana pada menit 1:04:11 yang mengatakan "Aku tidak butuh omong kosong itu, Saat kau tahu rencana besarmu, itu saatnya kau memberitahumu”. Mereka berdua kemudian melakukan pencarian terhadap kelompok perubahan dan memasang keberpihakan politik pada kelompok perubahan. Seketika itu mereka melabelkan kelompok alien menjadi kambing hitam. Jika dalam penelitian sebelumnya, peneliti sebelumnya mengatakan dalam film ini terdapat unsur Konsumerisme yang dimuat di dalamnya. Dengan percakapan-percakapan yang membuat orang merasa bersalah akan selalu diminati (Winslow, 2007). Menurut (Burke, 1962) ini adalah manifestasi dari karakteristik yang tidak sempurna dari kepribadian manusia.

Namun dalam penelitian ini, peneliti tidak meneliti bagaimana unsur konsumerisme yang terjadi pada objek penelitian terdahulu, melainkan menjelaskan kegiatan pelabelan musuh atau victimage yang dilakukan John terhadap kelompok alien yang dinilai sedang menjajah bumi. Kelompok alien digambarkan sedang berkonflik dengan kelompok perubahan, kelompok alien disini memiliki label kambing hitam yang didasarkan pada aktivitas mereka yang dinilai oleh kelompok perubahan telah bersikap sewenang-wenang di bumi. Kelompok alien telah melakukan eksploitasi di bumi. Maka dari itu, kelompok alien layak untuk dijadikan kambing hitam dan pada film tersebut kelompok alien layak untuk diperangi. Data yang dikumpulkan dalam tabel/gambar harus dilengkapi teks naratif dan disajikan dalam bentuk yang mudah dimengerti. Jangan ulangi secara panjang lebar data yang telah disajikan dalam tabel dan gambar. Berikut contoh tabel:

\section{KESIMPULAN}

Mengetahui hal yang mendasar dari teori dramatisme Burke sangat penting dilakukan untuk bisa mendalaminya yang kemudian secara sahih pada teori dramatisme Burke dilakukannya analisis pentad dramatistik seperti penelitian terdahulu yang dijadikan dasar permasalahan penelitian. Namun dalam penelitian ini, penulis tidak melakukan analisis pentad dramatisitik karena dalam penelitian ini mencoba menelusuri ulang serta menambahkan kekurangan dari hal yang mendasar dari teori dramatisme yang digunakan oleh peneliti sebelumnya yang mengalisis sebuah temuan atau objek pada film "They Live 1988".

Dalam film tersebut, aktivitas dan pidato-pidato yang dilakukan dan disampaikan oleh kelompok perubahan banyak memberikan reaksi terhadap masyarakat termasuk John dan Frank. Bahkan John berhasil menumbangkan menara pemancar milik kelompok alien yang dinilai bersalah. Pada penelitian sebelumnya hanya disebutkan efek dari aktivitas kelompok alien yang dinilai memuat unsur konsumerisme. Pokok penting dari penggunaan dan hasil dari teori Dramatisme dalam sebuah kasuistik tidak ditemukan dalam penelitian ini. Asumsi-asumsi yang mendasar pada teori dramatisme juga tidak ditemukan, baik tinjauan teori dan hasil analisisnya. Maka dari itu, penelitian ini menambahkan dasar-dasar teori dramatisme Burke untuk memberikan pemahaman atau identifikasi yang mendasar pada teori dramatisme. Identifikasi dan rasa bersalah guilt menjadi sebuah proses awal atau pembahasan inti yang dibahas dalam penelitian ini.

Identifikasi dasar pada teori dramatisme dan rasa bersalah guilt didapatkan dalam penelitian ini melalui film "They Live 1988". Penulis menemukan keenam elemen 
mengidentifikasi dasar yang didalamnya meliputi: identifikasi, pola formal, framing, simbol yang ambigu, mistifikasi, kambing hitam. Dalam penelitian ini juga menemukan rasa bersalah guilt yang menjadi hal yang mendasar pada teori dramatisme. Victimage atau pengorbanan menjadi temuan dalam penelitian ini. Pelabelan kambing hitam atau penyematan musuh atas kondisi yang sedang terjadi pada kelompok alien dilakukan oleh John dan kelompok perubahan.

\section{DAFTAR PUSTAKA}

Arikunto, Suharsimi. Prosedur Penelitian: Suatu Pendekatan Prakti. Jakarta: Rineka Cipta, 2010.

Bobbitt, David A. The Rhetoric of Redemption: Kenneth Burke's Redemption Drama and Martin Luther King, Jr.'s "I Have a Dream" Speech. Lanham, MD: Rowman \& Littefield Publishers, 2004.

Brock, Bernard L., Robert L. Scott, and James W. Chesebro. Methods of Rhetorical Criticism: A Twentieth-Century Perspective. Detroit: Wayne State University Press, 1990.

Burke, Kenneth. A Grammar of Motives and a Rhetoric of Motives. Cleveland: World, 1962.

Burke, Kenneth. “A Grammar of Motives,” 1969. https://doi.org/10.1525/9780520341715.

Dowling, Ralph E. "Victimage and Mortification: Terrorism and Its Coverage in the Media." Terrorism 12, no. 1 (1989): 47-62. https://doi.org/10.1080/10576108908435760.

French, Sandra L., and Sonya C. Brown. "It's All Your Fault: Kenneth Burke, Symbolic Action, and the Assigning of Guilt and Blame to Women." Southern Communication Journal 76, no. 1 (2011): 1-16. https://doi.org/10.1080/10417940903419235.

Griffin, Emory A., Andrew Ledbetter, and Glenn Grayson Sparks. A First Look at Communication Theory. Tenthed. New York, NY: McGraw-Hill Education, 2019.

Hadi S, Ika Brianti, Endang Pratiwi Kurniawan, and Irwansyah. "Pengungkapan Diri Di Situs Media Sosial YouTube.” JURNAL LENSA MUTIARA KOMUNIKASI 5, no. 1 (2021): 42-51. https://doi.org/10.51544/jlmk.v5i1.1526.

Hansen, G. "Kenneth Burke's rhetorical theory within the construction of the ethnography of speaking.” Folklore Forum 27, (1996) 50-59.

Lahti, Yannick. "MAKE AMERICA GREAT AGAIN"A rhetorical analysis of campaign and presidential speeches by Donald Trump in 2016- 2017. Depository University of Jyvakyla/Jyvaskyla University Library, 2018.

Littlejohn Stephen W, Karen A. Foss, and John G. Oetzel. Theories of Human Communication. Eleventhed. Long Grove, IL: Waveland Press, Inc., 2017.

Neuman W. Lawrence. Metodologi Penelitian Sosial: Pendekatan Kualitatif Dan Kuantitatif. 7th ed. Jakarta: Indeks, 2017.

Novitasari, Latifah, Prayudi Prayudi, and Agung Prabowo. "Pentad Analisis Pada Film Legend of the Guardians." Jurnal ASPIKOM 2, no. 4 (2015): 224. https://doi.org/10.24329/aspikom.v2i4.73.

Putra, M K. Jokowi's Communication Dramatism On Mass Media During The 2019 Presidential Election. Mass Media And Technology, 2020.

Satjakoesoemah, Alan, Sarah Vania Rizky, and Elviera Joelanda Sharinta. "Analisis Dramatistic Pentad Unsur Konsumerisme Dalam Film They Live 1988.” J-IKA 7, no. 1 (2020): 6267. https://doi.org/10.31294/kom.v7i1.8038.

Shearer, Allan W. “Applying Burke's Dramatic Pentad to Scenarios.” Futures 36, no. 8 (2004): 823-35. https://doi.org/10.1016/j.futures.2004.01.009. 
Sihombing, M. "PENGARUH KOMUNIKASI MELALUI GRUP WHATSAPP UNTUK MENINGKATKAN KINERJA KARYAWAN DI HOTEL GRANDHIKA MEDAN." JURNAL LENSA MUTIARA KOMUNIKASI, 1(1), (2018): 33-42. Retrieved from http://e-journal.sari-mutiara.ac.id/index.php/JLMI/article/view/308

Ulwani, Rahmi Fitra, Mailin Mailin, and Zainun Zainun. "Strategi Komunikasi Al-Ittihadiyah Sumatera Utara Dalam Mengembangkan Dakwah Di Sumatera Utara." JURNAL LENSA MUTIARA KOMUNIKASI 5, no. 1 (2021): 10-20. https://doi.org/10.51544/jlmk.v5i1.1496.

Winslow, L. A Discourse of Redemption: The Rhetoric of Dr. Phil. Conference Papers -National Communication Association. Washington D.C.: National Communication Association, 2007. 